\title{
POTENTIAL EFFECT OF MACRO ALGA Caulerpa sp. AND Gracilaria sp. EXTRACT LOWERING MALONDIALDEHYDE LEVEL OF WISTAR RATS FED HIGH CHOLESTEROL DIET
}

\author{
K. Srie Marhaeni Julyasih ${ }^{1 *}$ and I G. P. Wirawan ${ }^{2}$ \\ ${ }^{1}$ Faculty of Agriculture, UPN"Veteran" East Java \\ ${ }^{2}$ Faculty of Agriculture, University of Udayana, Bali-Indonesia \\ *Corresponding author: smjulyasih@gmail.com
}

\begin{abstract}
Seaweed has potential nutrient content such as carotenoids, vitamins, fatty acids, carbohydrates, minerals, and other essential substances. Carotenoids have important biological functions as an antioxidant, and immunostimulatory which can prevent the disease, anti-inflammatory, anti-stress, anti-aging, and protect the skin from the harmful effects of ultraviolet radiation. Seaweed generally consumed as a vegetable by people in Bali, known as the local name Bulung Boni (Caulerpa spp.) and Bulung Sangu (Gracilaria spp.).. So far there has been no report or results of research on the effects of extract ethanol of Bulung Boni (Caulerpa sp.) and Bulung Sangu (Gracilaria sp.) as an antioxidant that can prevent lipid peroxidation which can be seen in decreased level of MDA in liver tissue or blood plasma. Therefore it is necessary to determine of plasmaMDA level of Wistar rat after fed high cholesterol diet treated with extract ethanol of Caulerpa sp. and Gracillaria sp. This experimental study used Completely Randomized Design. Research using total of 24 Wistar rats divided into six sample groups of equal size, all fed with a diet high in cholesterol especially in negative control. The study consisted of negative control group (standard diet), positive control group (high cholesterol diet), high-cholesterol diet with Caulerpa sp. extract dose of 20 $\mathrm{mg}$ and $60 \mathrm{mg} / 100 \mathrm{~g}$, high cholesterol diet with Gracilaria sp. extract dose of $20 \mathrm{mg}$ and $60 \mathrm{mg} / 100 \mathrm{~g}$ body weight rat per day.The study resulted that rats fed high cholesterol diet with treated extract ethanol Caulerpa sp. and Gracilaria sp. with a dose of $20 \mathrm{mg}$ and $60 \mathrm{mg}$ per $100 \mathrm{~g}$ body weight rat / day had plasma MDA level significantly lower $(\mathrm{p}<0.05)$ compared with rats fed high cholesterol diet without treated with extract of Caulerpa sp. and Gracilaria sp.
\end{abstract}

Keywords: Caulerpa sp., Gracilaria sp., MDA, and seaweeds

\section{INTRODUCTION}

In some countries such as Japan,

Korea, China, Vietnam, Indonesia, Peru,

Scandinavia, Scotland, and Philippines,

seaweed has been used as a source of

food, medicine, and raw material for various types of industries. Seaweed has

potential nutrient content such as carotenoids, vitamins, fatty acids, carbohydrates, minerals, and other essential substances. Carotenoids have important biological functions as an 
POTENTIAL EFFECT OF MACRO ALGA Caulerpa sp. AND Gracilaria sp. EXTRACT LOWERING

antioxidant, and immunostimulatory an indicator of lipid peroxidation by free which can prevent the disease, anti- radical (Aksoy et al., 2003).

inflammatory, anti-stress, anti-aging, and Normally the body has a systematic protect the skin from the harmful strategy to counteract the free radical or effects of ultraviolet radiation (Kato et to accelerate degradation of these al., 2004; El-Baky et al., 2007). compounds. This system can be divided Carotenoids are antioxidant that are into two groups: preventive defense potential in protecting against membrane systems such as the enzyme superoxide lipid peroxidation (Siems et al., 2002). dismutase (SOD), catalase, glutathione Carotenoids are derived from natural peroxidase, and defense systems through sources more safe than synthetic the termination of radical reaction such as carotenoids (Allan, 2006). $\alpha$-tocopherol, vitamin $\mathrm{C}$, and carotenoids

Antioxidant can protect the body (Kumalaningsih, 2007). Antioxidant from free radical attack and reduce its compounds derived from plants such as negative impact. Free radicals are vitamin $\mathrm{C}$, vitamin $\mathrm{E}$, carotenoids, necessary for the survival of several phenolic groups, especially polyphenols, physiological processes in the body, and flavonoids have potential effect to especially for electrons transport, but the reduce the risk of degenerative diseases excessive free radical can harm the body (Amrun et al., 2007).

because it can damage macromolecules In addition besides effects of such as protein in cells, and DNA oxidants, cholesterol also affects the (deoxyribo nucleic acid). development of degenerative diseases. Macromolecular damage can improve The development of people live style cell death (Haliwell, 2002). that consume more fatty foods, especially Malondialdehyde (MDA) can be used as of saturated fatty acid intake tend to 
cholesterol to be higher than the level of need. Intake of foods with high cholesterol content can increase cholesterol levels in the blood. This condition called hypercholesterolemia. One of the major atherosclerosis risk factors are dyslipidemia, and the prevalence of dyslipidemia in Indonesia has increased (Anwar, 2006).

The treatment of patients with hypercholesterolemia require a long time, and high costs, the research continues to be developed to obtain a more effective drug with a cheaper price, and reduce side effects. Various studies of antioxidants also still needs to be done considering the huge benefits for health. Natural ingredients from the sea needs to be explored because the content of its bioactive especially antioxidants has not been thoroughly explored. As one effort to optimize the utilization of marine natural products of Indonesia, it is necessary to do research on seaweed.
In Bali there are several types of seaweed that is generally consumed by people known as the local name Bulung Boni (Caulerpa spp.) and Bulung Sangu (Gracilaria spp.). Seaweed is often consumed as a vegetable or snack and have been consumed hereditary. So far there has been no report or results of research on the effects of Bulung Boni and Bulung Sangu extract as an antioxidant that can prevent lipid peroxidation which can be seen in decreased level of MDA in liver tissue or blood plasmaThe results can provide information to the public about Bulung Boni and Bulung Sangu benefits can be used as natural antioxidants to prevent the effects of free radicals which is one risk factor for the development of degenerative diseases.

\section{MATERIALS AND METHODS}

The study was conducted with Experimental research measurement the levels of plasma malondialdehyde Study using completely randomized design 
POTENTIAL EFFECT OF MACRO ALGA Caulerpa sp. AND Gracilaria sp. EXTRACT LOWERING

MALONDIALDEHYDE LEVEL OF WISTAR RATS FED HIGH CHOLESTEROL DIET

K. Srie Marhaeni Julyasih and I Gede Putu Wirawan

(Murdiyanto, 2008). The study

consisted of negative control group rats

(standard diet), positive control group In one cage was placed as many as

(high cholesterol diet), rats fed high- four rats that had previously adapted for

cholesterol diet with Bulung Boni extract one week in the laboratory. Standard

dose of $20 \mathrm{mg}$ and $60 \mathrm{mg} / 100 \mathrm{~g}$, rats fed diet, cholesterol diet, and beverages rats

high cholesterol diet with Bulung Sangu administered daily ad libitum. Seaweed

extract dose of $20 \mathrm{mg}$ and $60 \mathrm{mg} / 100 \mathrm{~g}$ extract was administered orally by

body weight rat per day.

zonde with dose $20 \mathrm{mg}$ and $60 \mathrm{mg} / 100$

Seaweeds was collected from $\mathrm{g}$ body weight rat/day according to

Serangan Beach Bali. As for the further treatment.

analysis carried out at the Laboratory

of Healthy Plant, UPN "Veteran" Jawa Measurement of MDA Level

Timur, Agricultural Biotechnology

After 30 days treatment, rats was

Laboratory Udayana University and fasted for 18 hours. Bloods sample was

Laboratory of Pharmacology Faculty of taken through the sinus orbitalis as

Medicine Udayana University. much as 2 cc. Measurement of MDA

levels using Thiobarbituric Acid Reactive

Preparation of seaweeds extract

Substances (TBARS). (Rahayu, 2005).

Seaweed is dried and then

crushed in a blender, mixture with ethanol filtered

by filter paper Whatman 42 , evaporated

with vacuum evaprator to result crude extract..

\section{Data analysis}

Statistical analysis of data using

SPSS for windows. To determine the effect of treatment, the data were analyzed by analysis of variance at a significance level of $5 \%$. If the F-test 
showed a significant difference then,

further treatments were tested with LSD

at the $5 \%$ significance level.

\section{RESULTS AND DISCUSSION}

The lowest plasma MDA level level of $5.91 \pm 0.22 \mathrm{mg} / \mathrm{dl}$ (Fig. 1).
$2.41 \pm 0.10 \mathrm{mg} / \mathrm{dl}$, Gracilaria $60 \mathrm{mg}$ is $2.71 \pm 0.17 \mathrm{mg} / \mathrm{dl}$, Caulerpa $20 \mathrm{mg}$ is $3.22 \pm 0.47 \mathrm{mg} / \mathrm{dl}$, Gracilaria $20 \mathrm{mg}$ is $3.31 \pm 0.19 \mathrm{mg} / \mathrm{dl}$, and the highest in the positive control with plasma MDA

found in the negative control is 1.88

$\pm 0.22 \mathrm{mg} / \mathrm{dl}$, then Caulerpa $60 \mathrm{mg}$ is

\section{Plasma MDA Level}

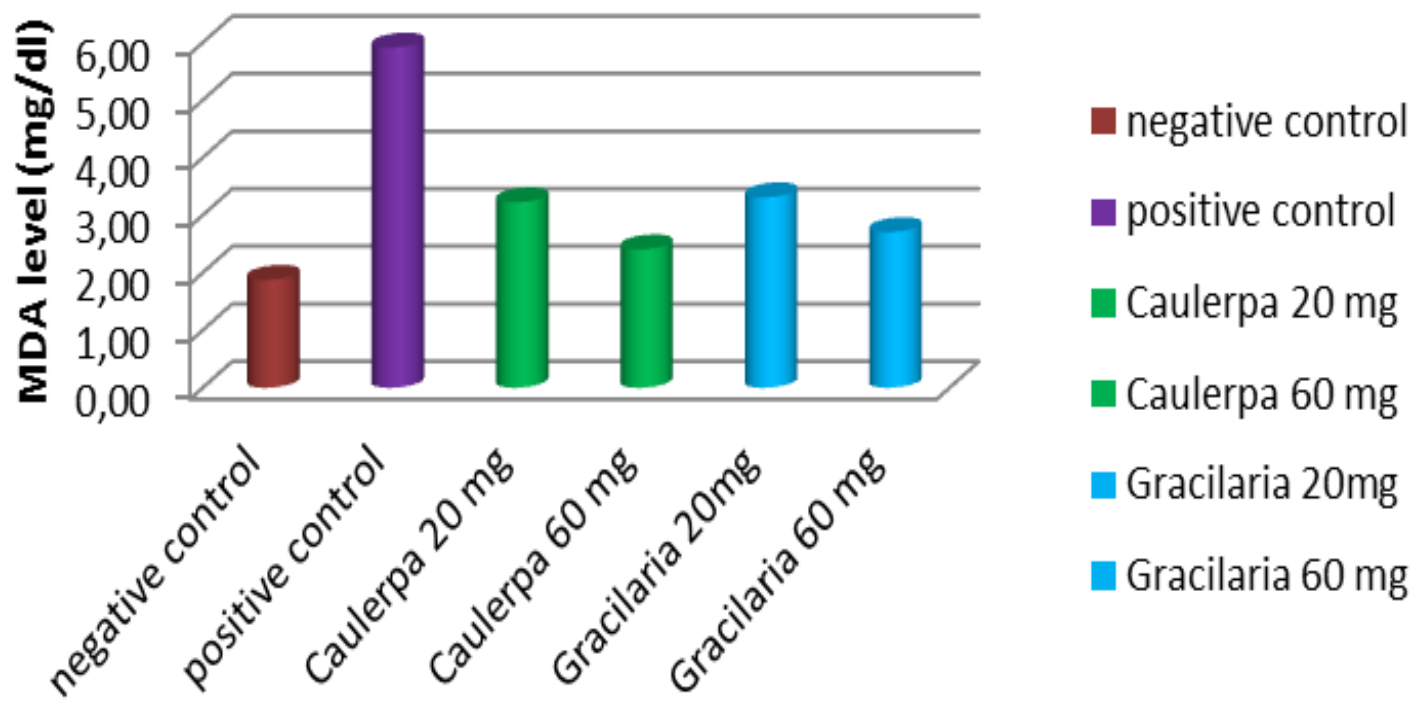

Fig. 1. Plasma MDA Level Wistar Rat in Negative Control, Positive

Control, Caulerpa $20 \mathrm{mg}$, Caulerpa $60 \mathrm{mg}$, Gracilaria $20 \mathrm{mg}$, and Gracilaria $60 \mathrm{mg}$.

Analysis of variance of plasma (Caulerpa sp.) and Bulung Sangu MDA level Wistar rat treated high- (Gracilaria sp) extract showed cholesterol diet with Bulung Boni significantly different $(\mathrm{p}<0.05)$ in various 
treatments. To determine the effect of concentration of MDA in the biological each treatment on plasma MDA level material can be used as an indicator performed with multiple comparation test. of damage okdidatif in unsaturated Plasma MDA level in Caulerpa $60 \mathrm{~m}$ fats, as significantly lower compared with well as an indicator of the presence of Caulerpa $20 \mathrm{mg}$, Gracilaria $20 \mathrm{mg}$, and free radicals.

positive control, but did not differ MDA analysis is an analysis of free significantly with Gracilaria $60 \mathrm{mg}$. radicals indirectly and easily determine Plasma MDA level in negative control the number of free radicals are significantly lower compared with other formed. Analysis of free radicals directly treatment. is very difficult to do because the

Provision of high-cholesterol diet radicals are very unstable. Measurements resulted in plasma MDA levels were can be made by reacting MDA TBARS significantly higher than other treatments, (Hurry et al., this is likely due to the oxidative 2002). Provision of high-cholesterol diet damage to the unsaturated fat. The fatty and extracts Caulerpa $20 \mathrm{mg}$ or acid chain polyunsaturated phospholipid Gracilaria per $100 \mathrm{~g}$ bw rat per day, can membrane layer is attacked by reduce levels of MDA plasma, thus hydroxyl radicals cause lipid significantly lower than rats that were peroxidation. Hoarding on the membrane only given high cholesterol diet. The lipid hydroperoxide will cause extract Caulerpa sp and Gracilaria sp. interference with the function of cells. with a higher dose of $60 \mathrm{mg}$ per $100 \mathrm{~g}$ Lipid peroxides can then be turned into bw rat resulted in an average of plasma toxic compounds, namely aldehydes, MDA levels were significantly lower MDA, and hydroxy nonenal. The compared with to Caulerpa $20 \mathrm{mg}$, 
Gracilaria $20 \mathrm{mg}$, and positive control..

Increasing doses of the extract resulted in

more active ingredient in the extract, so

the ability to reduce levels of plasma

MDA higher. Carotenoids are

antioxidants and can capture free

radicals. According Ardiansyah (2007),

the antioxidant defenses naturally in

LDL cholesterol by an amount sufficient

to protect $\mathrm{LDL}$ from oxidation. Beta

carotene is a fairly strong antioxidants

which theoretically also can protect LDL

oxidation.

\section{CONCLUSIONS}

Plasma MDA level of Wistar rat fed

high cholesterol diet treated with

Caulerpa sp. and Gracilaria sp. extract

with doses of $20 \mathrm{mg}$ and $60 \mathrm{mg}$

significantly lower compared with Wistar

rat fed high-cholesterol diet without

treated Caulerpa sp. and Gracilaria sp.

extract.The lowest plasma MDA level

found in the negative control is 1.88

$\pm 0.22 \mathrm{mg} / \mathrm{dl}$, then Caulerpa $60 \mathrm{mg}$ is
$2.41 \pm 0.10 \mathrm{mg} / \mathrm{dl}$, Gracilaria $60 \mathrm{mg}$ is

$2.71 \pm 0.17 \mathrm{mg} / \mathrm{dl}$, Caulerpa $20 \mathrm{mg}$ is

$3.22 \pm 0.47 \mathrm{mg} / \mathrm{dl}$, Gracilaria $20 \mathrm{mg}$

is $3.31 \pm 0.19 \mathrm{mg} / \mathrm{dl}$, and the highest in

the positive control with plasma MDA

level of $5.91 \pm 0.22 \mathrm{mg} / \mathrm{dl}$.

\section{REFFERENCES}

Adam, J. M. F. (2005). Meningkatkan Kolesterol HDL, Paradigma Baru Penatalaksanaan Dislipidemi. J.Med Nus, 26(3): 200-204.

Aksoy, H., Koruk, M., \& Akcay, F. (2003). The Relationship between

Serum Malondialdehyde and Ceruloplasmin in Chronic Liver Disease. Turkish Jurnal of Biochemistry, 28(2): 32-34.

Alan, M. (2006). Carotenoids and Other Pigments as Natural Colorants. Pure Appl.Chem, 78 (8): 1477-1491

Anwar, T.B. (2004). Dislipidemia Sebagai Faktor Resiko Penyakit Jantung Koroner. e-USU Repository

Anonim. (2008). Algal Pigments. Available at: URL:http://www.clarku.edu/faculty/ Robertson/laboratory $20 \%$ methods/p igments.html. 5 September 2010.

Ardiansyah. (2007). Antioksidan dan Peranannya Bagi Kesehatan. Available from:URL: http://www.iptek.net. 23 Januari 2007.

Burtin, P. (2002). Nutritional Value of Seaweeds. Electronic Journal of Enviromental, Agricultural and Food Chemistry, ISSN: 1579-4377.

Colpo, A. (2005). LDL Cholesterol: Bad Cholesterol, or Bad Science. Journal of American Physicians and Surgeons, 10 (3): 83-89 
Crowe, K. (2005). Plant Pigment Chemistry: Pigment Extraction and Analysis using Thin Layer Chromatography. University of Marine.

El-Baky, H. H., El-Baz, F. K., \& ElBaroty, G.S. (2007). Production of Carotenoids from Marine Microalgae and its Evaluation as Safe Food Colorant and Lowering Cholesterol Agents. American Eurasian J.Agric. Sci, 2(6): 792800.

Fuhrman, B., Elis, A., \& Aviran, M. (2002). Hyphocholesterolemic Effect of Lycopene and $\beta$ carotene is Related to Support of Cholesterol Synthesis and Augmentation of LDL Receptor Activity in Macrophages. Biochemical and Biophysical Research Comunicated. 232(3): 658-662.

Haliwell, B. (2002). Food Derived Antioxidants: How to Evaluate Their Importance in Food and in Vivo. Hand book of Antioxidants. Second Edition. Revised and Expandee Edited by Erique Cadences Lester Packer. University of Southern California School of Pharmacy. Los Angeles California. p 1-33.

Hangbao, M., Young, J., \& Shen, C. (2008). HMG-CoA Reductase (3 hydroxy-3 methyl glutaryl-CoA Reductase) (HMGR). Journal of American Science. 4 (3). ISSN 1541003.Availablefrom:

URL:http://www.americanscience.o $\mathrm{rg}$

Jae, K.W. (2008). Kolesterol. Yayasan Jantung Indonesia. Available from: URL:http://www.heartinfo.org. 17 September 2008.

Kagami, S. I., Kanari, H., Suto, A., Fujiwara, M., Ikeda, K., Hiroshe, K., Hikowatanabe, N., Iwanoto, I., \& Nakajima, H. (2008). HMG-CoA reductase Inhibitor Simvastatin Inhibit Proinflamatory Cytokine
Production from Marine Mast Cells. Int.Arch Allergy Immunol, 146(1): 61-6

Kato, M., Ikona, Y., Matsumoto, H., Sugiura, M., Hyodo, H., \& Yano, M. (2004). Accumulation of Carotenoids and Expression of Carotenoids Biosynthetic Genes During Maturation in Citrus Fruit. Plant Physiol February, 134 (2): 824-837. Liang Song, B., Javitt, N. B., \& Boyd, R. A. D. (2005). Insig Mediated Degradation of HMGCoA reductase Stimulated by lanosterol, an Intermediate in The Synthesis of Cholesterol. Cell Metabolism, 1: 179-189

Murdiyanto, B. (2008). Rancangan Percobaan. Available from URL: http://www.ikanlaut.tripod.com. 7 Juli 2009.

Myers, S. (2005). The Carotenoids Palette. An Array of Colors, Researched Health Benefits and Formulation Challengers Highlight the Future of Carotenoids. Available from:

URL: http://www.naturalproductsinsider.c om. 23 Juni 2007.

Pengembangan dan Pemanfaatan Obat Bahan Alam. (1991). Pedoman Pengujian dan Pengembangan Fitofarmaka. Penapisan Farmakologi, Pengujian

Fitokimia, dan Pengujian Klinik. Kelompok Kerja Ilmiah. Jakarta: Yayasan Pengembangan Obat Bahan Alam Phyto Medica.

Rahayu, T. (2005). Kadar Kolesterol Darah Tikus Putih (Rattus norvegicus L) Setelah Pemberian Cairan Kombucha Per-Oral. Jurnal Penelitian Sains \& Teknologi, 6(2): $85-100$.

Siems, W.G., Sommerburg, O., \& Frederick, J. G. M. (2002). Hand book of Antioxidants. Second Edition. Revised and Expandeed Edited by Erique Cadences Lester Packer. University of Southern 
INTERNATIONAL JOURNAL OF BIOSCIENCES AND BIOTECHNOLOGY • Vol. 5 No. 1 • September 2017

California School of Pharmacy. Los

Angeles California. p 235-245

Suharto., Girisuta, B., \& Miryanti, A.

(2004). Perekayasaan Metodologi

Penelitian. Penerbit Andi

Yogyakarta. 218p 